\title{
Fragmented Ethnopolitical Social Representations of a Territorial Peace Agreement: The Mindanao Peace Talks
}

\author{
Cristina Jayme Montiel, Judith M. de Guzman and Ma. Elizabeth J. Macapagal \\ Ateneo de Manila University, Philippines
}

\begin{abstract}
This article examines fractures in the social representations of a contested peace agreement in the longstanding territorial conflict of Mindanao. We compared representational structures and discourses about the peace talks among Muslims and Christians. Study One used an open-ended survey of 420 Christians and Muslims from two Mindanao cities identified with different Islamised tribes, and employed the hierarchical evocation method to provide representational structures of the peace agreement. Study Two contrasted discourses about the Memorandum of Agreement between two Muslim liberation fronts identified with separate Islamised tribes in Mindanao. Findings show unified Christians' social representations about the peace agreement. However, Muslims' social representations diverge along the faultlines of the Islamised ethnic groups. Findings are examined in the light of ethnopolitical divides that emerge among apparently united nonmigrant groups, as peace agreements address territorial solutions. Research results are likewise discussed in relation to other tribally contoured social landscapes that carry hidden, yet fractured ethnic narratives embedded in a larger war storyline.
\end{abstract}

Keywords: Mindanao, territorial conflict, ethnic identities, peace talks, social representations, hierarchical evocation method

The southern island of Mindanao in the Philippines has been the politico-military arena of a longstanding territorial conflict (Bertrand, 2000; Buendia, 2005) often described as a Muslim-Christian clash (Milligan, 2001; Tan, 2000). However, Mindanao is not only the Philippine hotbed of territorial conflict, it is also a region in which several peace initiatives have taken place. During the Marcos regime, and especially after the People Power Revolution in 1986 ushered in a new democracy, different Philippine presidents have attempted to establish peace in Mindanao. In 2008, a peace agreement called the Memorandum of Agreement (MOA) was signed by the peace panels of the Philippine government and the Moro International Liberation Front (MILF).

The MOA acknowledged two basic rights of the Moro people — identity and land. The peace agreement asserted the birthright of all Moros and indigenous peoples of Mindanao to claim their identities as Bangsamoros, delineated territorial boundaries that belonged to the Bangsamoro, and created the Bangsamoro Juridical Entity to hold authority over these defined territories. The public announcement of the MOA triggered a series of peaceful and armed protests among Christians, and counter-protests among Moro-associated forces. The Supreme Court eventually junked the peace agreement, and the Philippine president fired the government peace panel that she herself had constituted.

This recent peace fiasco likewise called attention to divisions among Muslims. With this recent unsuccessful attempt to establish peace in Mindanao, we investigated the nature of the psychological fractures within the Muslim front. We looked at how different Islamised groups in Mindanao made sense of the Memorandum of Agreement. However, as social psychologists who are Christians, we reflexively acknowledge our perceptive limitations as we attempted to understand political meanings held by two different Islamised tribes in what has been labelled a Muslim-Christian conflict. We viewed our research question through the lens of social representations theory, because this theory lends itself well to illuminating the subjective landscape of social conflict. 


\section{Social Representations Theory}

Social representations refer to shared knowledge about a social object. Such shared knowledge is socially constructed by group members who interact with each other (Moscovici, 1988). Social representations become powerful psychological realities in the public minds of members of a social group, and fuel collective group behaviour (Montiel, 2010). Social representations turn particularly dynamic when something new and unknown is introduced to a group, and as the group makes sense of this social novelty (Sarrica \& Contarello, 2004). In our study, this novel social concept was the Memorandum of Agreement for peace in Mindanao.

Social representations theory further identifies two group-based psychological processes involved in collective meaning-making, the processes of objectification and anchoring (Philogene \& Deaux, 2001). Objectification is concerned with transforming the abstract, in this case the peace agreement, into something concrete. Readily available information are selected and simplified (Abric, 1996). On the other hand, anchoring is the process of integrating this new information within a system of familiar categories. People attach labels (e.g., Muslim-Christian conflict) to the unfamiliar phenomenon (peace agreement), making possible the absorption of new information to an old setting which generates a system of interpretation and offers a framework for determining behaviour.

We posit that the Mindanao conflict was historically anchored on religious categories owing largely to political labelling by Spanish and American colonisers. The following section explains how the label 'Muslim-Christian conflict' evolved from a history of Mindanao marked by Christian foreign intrusions and Muslim resistance. We then discuss the ethnic contours of Islamised tribes and link this to divided social representational anchorings of a territorial peace agreement. We further argue that during peace talks, social representations of territorial agreements are anchored not only along religious lines, but also along ethnic contours among the nonmigrant landattached groups.

\section{Historical Anchoring: Using Religious Labels to Make Sense About Subverting Muslim-populated Mindanao}

Islam reached Mindanao sometime in the 10th century or at the latest by the 14th century, through Arab traders going to China from the Arabian Peninsula (Frake, 1998; Majul, 1973). The Arabian traders travelled through Malaysia, Mindanao, and other parts of the Philippine archipelago, to reach China. Islam entered and settled in Mindanao without any invasion or conquest involved among the local people of Mindanao (Frake, 1998).

The first religious label in the context of armed conflict emerged in the 16th century when the Spanish colonial forces repeatedly and unsuccessfully attempted to conquer the island of Mindanao which was, at that time, largely populated by Islamised tribes. The 16th century
Spanish colonisers called the local Mindanao population Moro, the same name the Spaniards used for their Muslim enemies in Spain, the Moors (Frake, 1998). However, the Islamised tribes did not call themselves Moros during the Spanish times. Note that the label Moro was a religious category connoting outstanding fierceness during combat. By the close of the 19th century, Spain ceded the Philippine Islands to America. During America's control over the Philippines in the first half of the 20th century, religious categories were again used in Mindanao, but the narrative shifted from military positioning by the Spaniards to economic positioning under American control. Mindanao Christians were largely favoured to own bigger tracts of land, through a law that structured the distribution of public land in Mindanao.

The Public Land Act or the Commonwealth Act 141 of 1936 used the religious labels 'Christians' and 'nonChristians'. The Public Land Act allowed a Christian to buy a maximum of 144 hectares of land while a nonChristian could only acquire not more than four hectares (Montiel, de Guzman, Inzon, \& Batistiana, 2010). Hence under America's colonial influence, economic dispossession of Muslim Mindanaoans was implemented through the religious label of 'non-Christian'.

The above examples demonstrate how the MuslimChristian religious anchoring was evoked in colonial narratives of conflict in Mindanao. However, these religious categorisations were not initiated by Muslims in Mindanao, but by Christian Spaniards, Americans, and their Filipino allies, in attempts to conquer Islamised tribes in Mindanao through military and economic strategies.

Only in the recent past have the Mindanao Muslims claimed the label 'Moro' for themselves (Frake, 1998). They have done so in the context of their politico-military territorial struggle in Mindanao against the Christiandominated Republic of the Philippines. When the Mindanao war exploded in the early 1970s, the organisation that spearheaded the struggle for territorial rights against the Philippine government was the Moro National Liberation Front (MNLF). By the 1980s a second politicomilitary group for territorial independence/autonomy in Mindanao likewise turned more politically visible, under the banner Moro Islamic Liberation Front (MILF). Both the MNLF and MILF have reclaimed the name 'Moro', reviving the image of fierce fighters for independence against foreign intruders.

Both liberation groups say that they are fighting for an independent/autonomous Bangsamoro or Moro Nation. Hence, the marginalised groups evoke a religious anchoring in the conversation about the Mindanao conflict. Their battle cry is a religious one, and is defined by the use of Moro in the names of the two primary liberation groups in Mindanao, and also by the expressed goal of both organisations which is the attainment of the Bangsamoro or the Moro nation. Even as the public discourse now moves from conflict to peacemaking, the same religious categories of war continue to be evoked in the Mindanao 
peace agreement. This is illustrated in the language used in the peace agreement (i.e., Memorandum of Agreement or MOA) to resolve territorial contentions in Mindanao. The MOA document explicitly recognises 'the birthright of all Moros and all Indigenous peoples of Mindanao to identify themselves and be accepted as Bangsamoros'. This call for Bangsamoro identity and homeland once more signifies a religious labeling. We ask however, if pragmatic peacemaking and talks about land sharing evoke ethnopolitical anchoring in addition to religious Muslim-Christian anchoring.

\section{Fragmented Social Representations of a Territorial Peace Agreement Among the Nonmigrant Groups}

Ethnopolitical groups define themselves by some combination of common ancestry, shared history, language, and valued cultural traits (Gurr \& Moore, 1997). Individuals who share a common descent and set of ancestors tend to share proximal space. Because ethnic groups live within defined territorial boundaries (Chandra, 2006), territorial conflict and peacebuilding efforts need to consider ethnopolitical faultlines as well (Harnischfeger, 2004). We predicted that such ethnopolitical contours existed not only as demographic and historical facts, but also as psychological spaces of fragmented subjective landscapes as well.

In the context of the Mindanao territorial conflict, territory is closely associated with ethnopolitical groups (Buendia, 2005). Tribal groups in Mindanao were present even before the arrival of Islam in Mindanao. At around the time Islam arrived in Mindanao through commercial traders, two dominant yet territorially distanced tribes had risen to politico-economic superiority and had formed two sultanates. These were the Tausugs in Jolo (Southwestern Mindanao) and the Maguindanao/Maranao tribes in Central Mindanao (Frake, 1998). Both Tausugs and Maguindanaoans/Maranaos lived in ethnic societies glued together by tribal loyalties, languages, kinship ties, and territorial spaces defined even before the coming of Islam. Maguindanaoans and Maranaos live closer to each other, interact more often, and are friendlier to each other than to the Tausugs. Henceforth, for parsimonious reading, we refer to the Maguindanao/Maranao ethnic groups as the Maguindanaoans.

Although both Islamised tribes had historically spearheaded resistance movements against Christian colonial and domestic forces, both Tausugs and Maguindanaoans remained relatively unaware of the Other Islamised tribe. Both ethnic groups did not relate with each other frequently, because they were spatially separated and the defence of their lands only required local rather than Mindanao-wide efforts. They could not communicate with each other because they did not share a common language. They possessed two distinct tribal languages, with each language incomprehensible to the other tribe (Frake, 1998).
After the 1960s, the term Moro was claimed by the liberation movements among the Islamised tribes. The leading ethnic groups formed two distinct politico-military organisations, with the Tausugs consolidating under the banner of the Moro National Liberation Front (MNLF), and the Maguindanaoans rallying under the Moro Islamic Liberation Front (MILF) (Bertrand, 2000; Buendia, 2005; Frake, 1998). Bangsamoro (Moro nation) became a battle cry for the various Muslim liberation groups. But the singular call for a Bangsamoro did not reflect operational unity between the MNLF and the MILF.

The term Moro was used primarily as a linguistic tool to distinguish Islamised tribes from the Christian world. The religious label bound Muslim Mindanaoans only when they engaged in macro political conversations with Christians. As Kreuzer (2005) emphasised, 'Bangsamoro ... unifies the various Moro groups only to a small degree. It is relevant politically in order to be heard by the Philippine government or the international donor community ... In terms of content, the bands are weak, the Muslims see themselves as members of their clans and ethnic group, and only secondary as Muslims' (p. 22). Thus, even if the nonmigrant group, the Muslims, claimed Bangsamoro, they remained ethnopolitically fragmented.

As a peace process emerges out of the rubble of a centuries-old conflict between Christians and Muslims, the peace narrative needs to address issues of territorial dominion. Interestingly, the central linguistic tool for peace talks fuses territory and ethnicity. The term 'ancestral domain' was the most contentious topic during the 2008 failed peace talks between the Philippine government and the Moro Islamic Liberation Front. Note that the label 'ancestral domain' describes control over territory (domain) that is associated with ethnic descent (ancestral).

As talk about the Memorandum of Agreement arises in the public sphere of conflicted Mindanao, how do different Mindanao groups make sense of this novel social object? Would representational anchorings about the peace agreement reflect the religious divide of a so-called Muslim-Christian conflict? A deeper question then arises about whether two nonmigrant and physically separated Islamised tribes can share a common understanding about one peace agreement. This question becomes crucial because bilateral peace talks assume that shared knowledge about a peace memorandum would be divided between Christians and Muslims, but unified within each of these groups.

Moscovici (1988) identified three ways by which representations interface with intergroup relations. Hegemonic representations are shared by all members of a society and appear to be uniform. Emancipated representations can be observed when social groups share similar representations, but highlight different aspects of these representations. Polemic representations, on the other hand, are antagonistic and arise during social conflict. These representations are evoked during social controversy and provide the subjective landscape of intergroup conflicts 
Table 1

Survey Sites Reflect the Political Duality of Islamised Tribes in the Mindanao Peace Conversation

\begin{tabular}{lll}
\hline Types of Political Dualities & \multicolumn{1}{c}{ Survey Site } & \\
\hline Dominant Islamised tribe in survey site & Cotabato City & Zamboanga City \\
Moro Liberation Front associated with each site & Maguindanaoan & Tausug \\
$\begin{array}{l}\text { Peace agreements (with the Christian-dominated Philippine } \\
\text { government) supported by each liberation front }\end{array}$ & Moro Islamic Liberation Front (MILF) & $\begin{array}{l}\text { Moro National Liberation Front (MNLF) } \\
\text { Label of claimed Mindanao territory used in the peace agreement }\end{array}$ \\
& $\begin{array}{c}\text { Memorandum of Agreement on } \\
\text { Ancestral Domain or MOA-AD }\end{array}$ & 1996 Final Peace Agreement \\
& Bangsamoro Juridical Entity (BJE) & $\begin{array}{c}\text { Autonomous Region in Muslim } \\
\text { Mindanao (ARMM) }\end{array}$ \\
\hline
\end{tabular}

(Montiel \& de Guzman, 2011). They tend to be contradictory and contested, as members of different social groups dispute the social meanings of a particular social object.

We predicted polemic representational anchoring about the Memorandum of Agreement, not only across the religious divide but also among the Islamised tribes. We expected polemic social representations of the peace agreement only among the nonmigrant Islamised groups rather than the Christian settler group, because the former carry tribal loyalties beyond an Islamic religion, and are attached to the contested territory. In territorial conflicts, ethnopolitical anchoring may be evoked more passionately by groups who have had centuries-old attachments to the contested land, rather than by the migrant or settler groups. Hence we did not expect any fractures in the social representations of the peace agreement among Christians.

\section{Ethnopolitical Social Representation of a Peace Agreement: Two Studies}

We ran two studies that asked the questions: Do social representations about the Memorandum of Agreement divide along the tribal faultlines of the Islamised groups? On the other hand, are social representations about the peace agreement homogeneous among Christians?

Study One surveyed college students and staff in selected territories of Mindanao associated with the Tausug and Maguindanao Islamised tribes. This study compared social representations of the peace agreement across religion and territory. According to Abric $(1996,2001)$, social representations have a stable central element called the central core, and more peripheral changeable elements. The central core is the main element because it determines the structure of the representation and verifies the relevance of the representation as whole. We used Abric's (2008) hierarchical evocation method to provide representational structures and identify central cores. Each group's representational central core was described, to find out if central cores about the peace agreement varied across groups.

Study Two used media analysis to identify social representations (Wagner et al., 1999) about the peace agreement. In the second study, we collected and analysed public utterances about the contested peace agreement by two ethnically identified Muslim liberation organisations, the Maguindanaoan-dominated Moro Islamic Liberation
Front and the Tausug-led Moro National Liberation Front (Betrand, 2000; Buendia, 2005; Frake, 1998). Study Two presents competing public storylines about the Memorandum of Agreement, as advanced by these two ethnicallydifferent Muslim resistance groups.

\section{Study One: Structure of the Social Representations of the Memorandum of Agreement Across Religious and Territorial Groups}

We ran our survey in two research sites with distinct Islamised populations: (1) Cotabato City, which is populated by the Muslim Maguindanaoan group; and (2) Zamboanga City, wherein Tausugs are the dominant Islamised tribe (National Statistics Office, 2002). We note at this point that the Maguindanaoans exert influence in the MILF whereas the Tausugs are known to be in control of the MNLF. Table 1 summarises the ethnopolitical duality of these two research sites, the Islamised tribes within these territories, and their alignments in Muslim liberation groups.

Our sampling design consisted of a $2 \times 2$ matrix, with participants categorised according to religion (Christian or Muslim) and territory (Cotabato or Zamboanga). We surveyed 420 participants from the Notre Dame University in Cotabato City $(n=193)$ and the Ateneo de Zamboanga University in Zamboanga City $(n=227)$. Both sampled universities were highly recognised private schools in their respective territories, and had produced regional leaders from their respective academic institutions. The Cotabato student sample consisted of 94 Christians and 99 Muslims. The Zamboanga sample had both students and staff respondents, with 144 Christians and 83 Muslims. Data collection did not pose any problem in both sample sites because we had personal contacts in both academic institutions. Further, at the time of data collection, the first author was a visiting professor at the Ateneo de Zamboanga University.

\section{Survey Instrument and Data Analysis}

The survey explored local people's social representations of the 2008 peace agreement. We asked participants to mark their position in relation to the following statements: (a) I am for the signing of the MOA (Memorandum of Agreement on Ancestral Domain), (b) I am not for the signing of the MOA, and (c) Others, please describe. We then computed for the percentage of participants who indicated 
Table 2

Representational Central-Core Elements of the Memorandum of Agreement, Across Religions and Territories

\begin{tabular}{|c|c|c|c|}
\hline & & $\begin{array}{c}\text { Territory } \\
\text { Zamboanga (Tausug)* }\end{array}$ & Cotabato (Maguindanaoan)* \\
\hline \multirow[t]{2}{*}{ Religion } & Christians & $\begin{array}{l}\text { Muslim control and domination }(18.83 \%, \mathrm{AEO}=1.66)^{* *} \\
\text { Territory, land and ancestral domain }(11.73 \%, \mathrm{AEO}=1.68)\end{array}$ & $\begin{array}{l}\text { Territory, land and ancestral domain }(17.34 \%, \mathrm{AEO}= \\
1.33) \\
\text { Separation of Mindanao from the Philippines }(16.18 \% \text {, } \\
\text { AEO }=1.57) \\
\text { Peace, order and development }(15.61 \%, \mathrm{AEO}=1.81) \\
\text { Muslim control and domination }(11.56 \%, \mathrm{AEO}=1.90)\end{array}$ \\
\hline & Muslims & $\begin{array}{l}\text { Territory, land and ancestral domain }(18.33 \%, \mathrm{AEO}=1.61) \\
\text { Feelings of uncertainty, confusion, mistrust, anger and fear } \\
(18.33 \%, \mathrm{AEO}=1.94)\end{array}$ & $\begin{array}{l}\text { Muslim rights, freedom and self-governance }(31.36 \% \text {, } \\
\text { AEO }=1.81)\end{array}$ \\
\hline
\end{tabular}

*Note: * The terms within parentheses refer to the name of the Islamised tribes in these particular territories.

** The percentages refer to the frequency of occurrence of each theme. AEO stands for the average evocation order or the average rank of each theme, where $1=$ most immediately evoked and $3=$ less immediately evoked.

their support for the signing of the MOA, across religious and territorial groups.

We also utilised a free word association task to investigate how participants socially represented the peace agreement. In this task, we asked participants to imagine themselves conducting a lecture about the peace accord. We then asked them to state the three most important features of the agreement that they would include in their lecture. We adopted a structural approach in analysing the data from the free word association task.

The structure of social representations may be studied through a quantitative method known as the hierarchical evocation method (HEM; Abric, 2008; Wachelke, 2008). Among other things, HEM identifies the central core of a social representation. The central core consists of the main elements of a social representation; it is 'stable, coherent, consensual, and considerably influenced by the group collective memory and its system of values' (Abric, 1996, p. 79).

Operationally, HEM identifies the central core of a social representation by examining two criteria - the frequency and the order of evocation of a representational element. Thus, central core elements refer to the responses that are mentioned more frequently (high frequency) and more immediately (low average evocation order) (Abric, 2008; Roland-Levy \& Berjot, 2009; Wachelke, 2008; Wolter, Gurrieri \& Sorribas, 2009).

Our data analysis using the hierarchical evocation method followed a two-stage process. First, we examined the responses to the free word association task using thematic analysis, a method that allowed us to identify meaningful patterns in the data (Braun \& Clarke, 2006). Because our aim was to identify central core elements - defined as those themes with high frequency and low evocation order, we excluded some themes that had significantly low frequencies (less than $5 \%$ of total responses; J. Wachelke, personal communication, May 7, 2012).

We then computed for the average frequency and the average evocation order of each theme. Because of the unequal group sizes, we utilised the percentage of occurrence of each theme. Readers may refer to Abric (2008) and Wachelke (2008) for more procedural details about the use of the hierarchical evocation method in social representations research.

\section{Results: Christian Hegemony and Muslim Fragmentation in the Social Representations of the Memorandum of Agreement}

Our findings show Christian hegemony and Muslim fragmentation in the social representations of the 2008 peace agreement. Figure 1 illustrates the patterns of support for the peace agreement across religions and territories. Our results showed that Christian participants from both locations opposed the peace accord. Table 2 presents the representational elements of the central core across religious and territorial groups. Specifically, our findings showed that some of the central core elements of the Christian representation of the MOA were shared across territories while other elements appeared to be unique only to Christian participants from one territory.

In particular, Christian participants from Cotabato and Zamboanga made sense of the peace agreement in relation to the following central core elements: (1) Muslim control and domination in Mindanao, and (2) issues about territory, land, and ancestral domain. However, it is important to note that the central core of the social representations held by Cotabato Christians included other elements, such as the meanings of the peace agreement in relation to peace, order, and development in Mindanao, as well as issues related to the separation of Mindanao from the Philippines. This indicates that although Christian groups from Cotabato and Zamboanga held hegemonic representations about the peace agreement, Christian participants from the former site may have a more complex representation about this particular social object.

More importantly, our findings revealed ethnopolitical fragmentation between the two Muslim groups in relation to the 2008 peace agreement. The majority of Tausug Muslim respondents opposed the peace accord. Interestingly, this Islamised group's social representations stood closer to those held by the Christian groups. Among the Tausugs, the social meanings of the said peace accord 

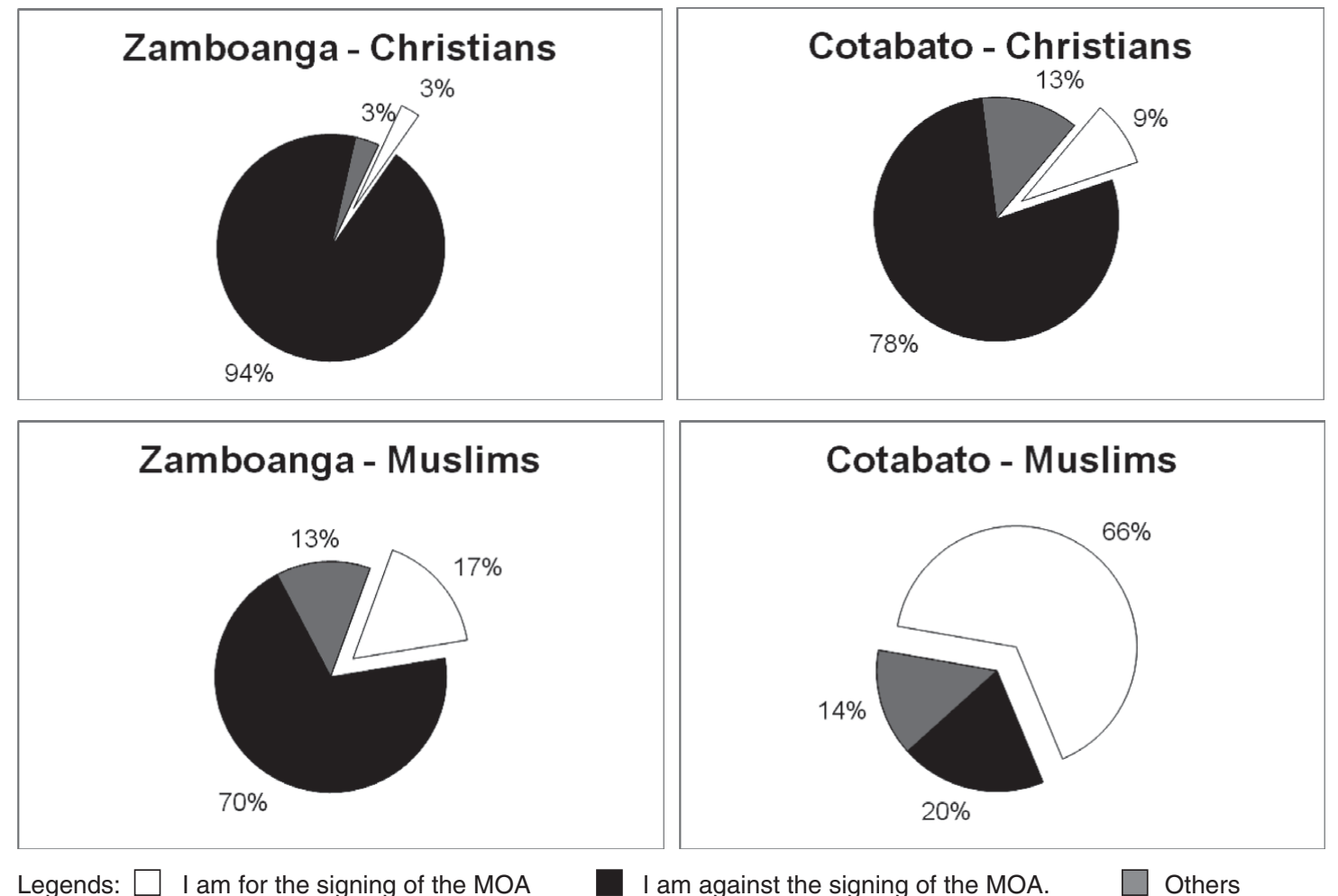

Legends:

I am for the signing of the MOA

I am against the signing of the MOA.

Others

\section{Figure 1}

Public support/opposition to the Memorandum of Agreement across religious and territorial groups.

were linked to (1) issues about land, territory, and ancestral domain, and (2) feelings of uncertainty, confusion, mistrust, anger, and fear. In contrast, the majority of Maguindanaoan Muslims supported the peace agreement. Maguindanaoans socially represented the Memorandum of Agreement as linked to Muslim rights, freedom, and self-governance. The representational fracture between Islamised tribes shows Tausug Muslims emphasising negative emotions, and Maguindanaoan Muslims explaining the peace agreement in a positive light. Table 3 lists down the themes that comprised the representational core elements of each subgroup along with sample responses that comprise each particular theme.

\section{Study Two: Public Meanings of the Memorandum of Agreement According to Two Ethnically-Different Muslim Liberation Movements}

Study One showed that Muslim participants from two different territories held fragmented representations about the 2008 peace agreement. Building on this finding, we further investigated the social meanings of this peace agreement according to two ethnically different Muslim liberation movements - the Moro Islamic Liberation Front (MILF) and the Moro National Liberation Front (MNLF). Social representations can also be studied by looking at the discourses that different social groups hold about a particular social object (Wagner et al., 1999).
To investigate the social representations of the 2008 peace agreement according to these two ethnopolitical groups, we gathered news articles and accounts regarding this social object from the following sources: (1) the internet version of the Philippine Daily Inquirer, the nation's most widely circulated newspaper, and (2) the official website of the MILF Central Committee on Information. We collected data that were published from July 2008 to April 2009, corresponding to the period when information about the peace accord first emerged in the public sphere up to the period when the contentions about the agreement started to subside. Through this process, we accumulated 169 articles and accounts. Most of the articles about the MOA involved the MILF, mainly because this liberation movement was the main proponent of this peace agreement. Nevertheless, our dataset also included some key accounts highlighting the position of the MNLF in relation to the controversial peace accord. We then extracted statements and arguments about the peace agreement that were issued by the MILF and the MNLF. Finally, we read and re-read these key utterances to identify the social meanings that these two ethnopolitical groups ascribed to this particular peace accord.

\section{Results: MILF-MNLF Polemical Representations about the Memorandum of Agreement}

Our findings showed that the two Muslim ethnopolitical groups - the Moro Islamic Liberation Front (MILF) 


\section{Table 3}

Sample Responses per Theme Generated From the Free Evocation Task About the Memorandum of Agreement

\begin{tabular}{|c|c|}
\hline Themes & Sample responses \\
\hline Muslim control and domination & $\begin{array}{l}\text { The Bangsamoro group are trying to take over ARMM. } \\
\text { Powers of the Muslim. } \\
\text { It extended the Muslim area. } \\
\text { The issue of possible Muslim domination. } \\
\text { Islam wants to be the most powerful. } \\
\text { The MILF will somehow try to dominate Mindanao (some parts). } \\
\text { Invasion of Islam. } \\
\text { Muslim domination in Mindanao. } \\
\text { The Bangsamoro wanted to occupy Mindanao. } \\
\text { Becoming Mindanao as the land for Muslim people only. } \\
\text { Forcefully claiming of Bangsamoro that Mindanao is the property of Muslims. }\end{array}$ \\
\hline Territory, land and ancestral domain & $\begin{array}{l}\text { Ancestral domain. } \\
\text { Territory. } \\
\text { Territorial limits and boundaries. } \\
\text { Taking back their land. } \\
\text { Land grabbing. } \\
\text { Ownership of land. } \\
\text { Bangsamoro homeland. } \\
\text { Division of land/geographic areas/barangays. } \\
\text { Inclusion of some barangays in the BJE. }\end{array}$ \\
\hline Separation of Mindanao from Philippines & $\begin{array}{l}\text { They will separate Mindanao from the Philippines. } \\
\text { Separation of Mindanao from Philippines. } \\
\text { Mindanao will be a country. } \\
\text { The independence of Mindanao. } \\
\text { Mindanao will be known as a country not just one part of the Philippines. } \\
\text { The economy of Mindanao is separated from the Philippines. }\end{array}$ \\
\hline Peace, order and development & $\begin{array}{l}\text { Peace between government and MILF. } \\
\text { Peace and order. } \\
\text { Stopping conflicts in the community. } \\
\text { It helps resolve conflict in Mindanao. } \\
\text { This is about the resolution of the problem in Mindanao for peace implementation. } \\
\text { For the betterment of Mindanao. } \\
\text { Unity of all Christians and Muslims. } \\
\text { Peace in Mindanao. } \\
\text { Development. } \\
\text { To have peace and justice for the people of Mindanao. } \\
\text { A solution for conflict. } \\
\text { It will give a long-lasting peace in Mindanao. }\end{array}$ \\
\hline Feelings of uncertainty, confusion, mistrust, fear and anger & $\begin{array}{l}\text { Not to be trusted. } \\
\text { Anger. } \\
\text { Scary. } \\
\text { I feel bad about it because suddenly popped out without info. } \\
\text { It made the Zamboanguenos panic. } \\
\text { Confusion among people caused by MOA. } \\
\text { What will happen if we will be a part of it? } \\
\text { What must have gone to the government's mind that they commit that stupidity? } \\
\text { The fear of what will happen to us. } \\
\text { What will happen to us if they are able to get our properties? } \\
\text { Christians will be afraid to stay in Zamboanga }\end{array}$ \\
\hline Muslim rights, freedom and self-governance & $\begin{array}{l}\text { Attain independence for Moros. } \\
\text { Muslim Mindanaon are liberated. } \\
\text { The right to Bangsamoro. } \\
\text { Independence will be given to Muslim people of Mindanao. } \\
\text { It has something to do with the independence of Muslim Mindanaoans. } \\
\text { Implementation of Islamic laws. } \\
\text { Muslim people will take a chance to lead in their own country. } \\
\text { Bangsamoro will be given leadership rights to rule Mindanao. } \\
\text { Bangsamoro republic } \\
\text { Right of self-determination. } \\
\text { Equal rights for Muslims. }\end{array}$ \\
\hline
\end{tabular}

and the Moro National Liberation Front (MNLF) — held polemic representations about the 2008 peace agreement. The social representations of the said peace accord varied between these two groups in terms of four main points: (1) the social and political consequences of the peace agreement, (2) the mechanism that each group proposed to 
Table 4

Ethnopolitical Fragmentation Between the Moro Islamic Liberation Front (MILF) and the Moro National Liberation Front (MNLF)

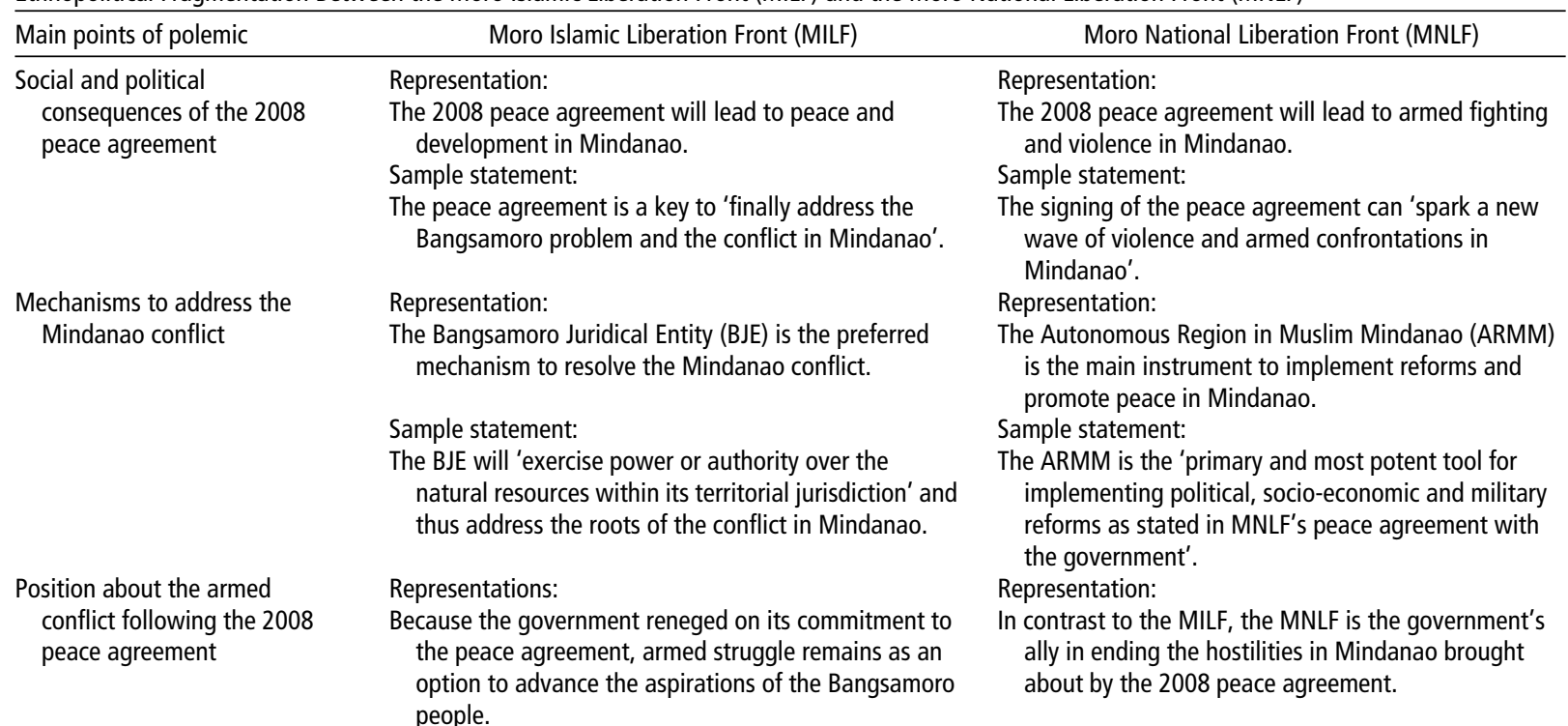

Government military troops initiated the armed fighting by harassing MILF troops.

Sample statements:

'War is among the options. It is part of the struggle. The The MNLF is willing to 'contribute towards the MILF is determined to continue that struggle.' restoration of peace' in Mindanao.

'The militiamen in these areas harassed MILF troops in nearby villages and that started all of these.' Suggestions for the future peace
process

Suggestions for the future peace process
Representations:

The peace agreement between the Philippine government and the MNLF has failed to address the Mindanao conflict; hence, the 2008 peace agreement should be used as the framework for the future peace process.

Sample statements:

The peace agreement between the Philippine government and the MNLF was 'not implemented satisfactorily years after the signing'.

The 2008 peace agreement is 'the only peaceful way to solve the Moro Problem'.
The MNLF is a 'partner of the national government in the implementation of peace and development for many, many years until today'.

Representations:

The peace agreement between the Philippine government and the MNLF provides the best possible solution to the Bangsamoro problem.

Sample statements:

The peace agreement between the Philippine government and the MNLF is 'the best under the present circumstances'.

'The 1996 MNLF-GRP accord should take precedence before any other agreements.' address the Mindanao conflict, (3) the positions that each group took in relation to the armed conflict that followed the controversy over the peace agreement, and (4) each group's suggestions on how to move the peace process forward. Table 4 shows the polemical themes that emerged from the collected utterances of these two ethnopolitical groups, along with sample statements from each group.

As the main proponent of the agreement, the MILF argued that the peace accord would lead to peace and development in the Mindanao region. In contrast, the MNLF cautioned that the agreement would precede armed fighting and violence in Mindanao. Polemic representations of the peace agreement were also observed in relation to the mechanisms that each group proposed to address the conflict in Mindanao. On the one hand, the MILFsponsored peace agreement recommended the creation of Bangsamoro Juridical Entities to enable the Bangsamoro people to exercise governance over their ancestral do- main and thus provide a solution to the conflict in the region. On the other hand, the MNLF reiterated the role of the existing Autonomous Region in Muslim Mindanao (ARMM) as the primary mechanism to implement the necessary reforms to promote peace in Mindanao. In addition, the MNLF also strongly opposed the inclusion of ARMM provinces in the territories claimed by the MILF in the Memorandum of Agreement.

A third point of divergence between the MILF and the MNLF involved the position that each ethnopolitical group took in relation to the armed fighting that erupted during the social controversy about the 2008 peace agreement. For the MILF, armed struggle remained to be one of the options to advance the aspirations of the Bangsamoro people. The MILF also argued that their field commanders engaged in armed confrontations with the government only as a defensive move. In contrast, the MNLF positioned itself as the Philippine government's ally by calling for a cessation of armed hostilities. 
Finally, as the controversy over the peace accord subsided, the MILF and the MNLF also held polemic representations about the possible avenues to move the Mindanao peace process forward. According to the MILF, the peace agreement between the Philippine government and the MNLF had failed to address the roots of the Mindanao conflict. Hence, the MILF-backed 2008 peace agreement represented the most effective tool to push the peace process forward. The MNLF strongly countered this assertion and instead highlighted the centrality of the previous peace agreements that it had negotiated with the Philippine government, citing how these accords represented the best possible option to end the Mindanao conflict.

\section{Summary: Highlights of Results}

Do the social representations of a territorial peace agreement vary in relation to ethnopolitical fragmentation between Muslim nonmigrant groups in Mindanao? Our findings from Study One showed that whereas Christian settlers held hegemonic representations about the 2008 peace agreement, Muslim nonmigrants from two distinct territories, Cotabato and Zamboanga, held fragmented representations in relation to this particular social object. Study Two further substantiates these findings by examining the social meanings which two Muslim ethnopolitical groups - the Moro Islamic Liberation Front (MILF) and the Moro National Liberation Front (MNLF) - ascribed to the 2008 peace agreement. Results supported the patterns of Muslim ethnopolitical fragmentation observed in Study One, as these two resistance groups illustrated polemic representations about the Memorandum of Agreement.

We point out that both studies showed how the Tausugassociated Muslims positioned themselves along with the Christians' contradictory stance against the peace agreement, leaving only the Maguindanaoan Muslims supporting the controversial peace proposition. Hence, the findings of our two studies provide evidence for the need to study ethnopolitical dynamics within a single religious category during the negotiation of territorial peace agreements in a so-called Muslim-Christian conflict.

\section{Discussion}

Using social representations theory as a conceptual lens, this research argued for representational fragmentations within the Muslim nonmigrant group rather than the Christian settler group, because different Islamised tribes carried ancestral attachments to separate territorial tracts included in the peace agreement. Research findings showed internal fractures along ethnic lines especially as the peace process progressed. From a shared religious category of the nondominant group Muslim or Moro, antagonistic ethnopolitical faultlines associated with particular ancestral domains emerged.

In the Mindanao conflict, war was encoded in the language of religious categories. Hence, at the peace bargain- ing table, the Christian government thought about one Muslim Front and a single unified Bangsamoro. But there was a different psychological picture on the other side of the bargaining table. Mindanao Muslims may not have seen all Islamised tribes as having equal collective rights over the territorial spoils of war. Fragmented ethnopolitical faultlines emerged as political talk veered away from an anti-Christian struggle to the sharing of power within Bangsamoro.

Our research highlights the power of social representations to nuance meaning-making within bigger social groups who are involved in peace talks. The conventional way of analysing conflict and peacemaking is through broader categories such as religion. But based on our results, viewing underlying ethnopolitical contours of larger conflict-based categories may add to a deeper understanding of a territorial peace process. Our results concur with other research findings that Muslims have an identity divide (Buendia, 2005; Frake, 1998). Bertrand (2000), for instance, observed that 'divisions among Muslims have reduced support for the peace agreement' (p. 49). In territorial conflicts, larger or deeper divides may emerge once the peace talks address territorial issues.

What are the practical implications of our findings? We first relate our results to peacebuilding in Mindanao, and then elucidate on implications in other tribally contoured conflicts in the Pacific Rim.

One implication is that understanding the nature of peace in Mindanao entails looking beyond a conventional clash-of-religions narrative. The Mindanao conflict is popularly labeled as a Muslim-Christian conflict. Attempts at peacebuilding include formation and training projects that widen cultural understandings and increase tolerance of each other's religions. But underneath the religious umbrella of the Islamised nonmigrant and displaced group, there are tribal contours that turn salient as peace talks discuss territorial dominion over land ceded by the dominant Christian state. Hence, peace discussions should include not only whether particular spaces would fall under Christians or Muslims, but also how the territory ceded to the Muslims would be shared and managed by the different Islamised tribes.

The recent peace fiasco of 2008 demonstrates how Islamised Tausugs positioned themselves against a Memorandum of Agreement that was backed by the Maguindanaoan-associated Moro Islamic Liberation Front. For an explanation, we look at intertribal political competition. The reason behind the Tausugs' criticism of the peace agreement may have stemmed from a collective Tausug desire for tribal control of any Moro Nation that would arise after the peace agreement. If the 2008 peace agreement had been signed, the Maguindanaoans would dominate the new Bangsamoro. This was probably what many Islamised Tausugs were avoiding as they criticised the 2008 peace agreement.

Long-lasting peacebuilding in Mindanao would entail addressing the politico-ethnic contours of Islamised tribes 
in the new Bangsamoro. However, the history of Mindanao peacemaking in the Philippines does not seem to recognise the underlying tribal contours. The discourse during peace talks is only about a single Muslim territory referred to, across recent history, as the Autonomous Region of Muslim Mindanao (ARMM) associated with the Tausugled Moro National Liberation Front, or the Bangsamoro Juridical Entity (BJE) in the 2008 failed peace agreement with the Maguindanao-influenced Moro Islamic Liberation Front. Understandably, both peace instruments did not mobilise a united Muslim front because support for or against the peace agreement fractured along tribal lines.

Assuming, however, that the peace discourse recognised ethnic coagulations, what would be the practical consequence on peacebuilding in Mindanao? We see two options. First, instead of a single Bangsamoro political entity, discussions may veer toward the creation of two Bangsamoro entities or substates, associated with the two dominant Islamised tribes in Mindanao.

A second option would be to open the doors to Muslim-based third party interventions that would encourage the liberation movements associated with the Tausugs and the Maguindanaoans to work together and craft the power-sharing contours of a single Bangsamoro state. Perhaps the superordinate goal of successfully getting back ancestral land now in the hands of Christians can bring the Islamised tribes together toward a more unified front. Informal and unverified political rumours have talked about the Organization of the Islamic Conference (OIC) organising such meetings between the MNLF and the MILF. For ethical and politico-psychological reasons, however, it is worthwhile to mention that all three of us authors are Christians who believe that such third party interventions should not be initiated by the Christianassociated Philippine government or nongovernment organisations, as the issue is an internal matter among Islamised tribes.

Our research findings may likewise hold practical implications for other ethnically contoured contestations in the Pacific Rim. In the North Atlantic, cultural melting pots and multiculturalism are characterised by migrants from different parts of the globe. In the Pacific Rim, however, cultural heterogeneity is marked by variations of nonmigrant cultural groups whose ancestors have lived on their lands for hundreds of years. Hence, tribal identities in the Rim emerge during contestations about dominion over territory and resources in a certain place.

We point out that a larger conflict storyline in the Pacific Rim may actually hold invisible yet powerful tribal contours which may emerge once the bigger enemy cedes territorial control to the nondominant group. This may be the future of peacebuilding in the so-called large conflict between Christians and Muslims in Mindanao. There are also other societies in the Pacific Rim that may likewise need to attend to smaller tribal identities associated with the nondominant group, once the bigger antagonist bows out partially or completely from the contested territory.
Aside from the Mindanao conflict, we cite two other social conflicts in Pacific Rim where tribal-based peacemaking issues may arise within the nondominant group, as the major conflict with the primary dominant group subsides. For example, the Aceh movement for independence from the Indonesian state has been fuelled by Acehnese nationalism. Yet a closer look at the political picture on the ground shows that the Acehnese nation is composed not only of the Aceh tribe, but also of other tribes (Schulze, 2003) that include the Gayonese, Alas, Tamiang, Ulu Singkil, Kluet, Aneuk Jamee, and Simeulu (McCulloch, 2005). In Papua New Guinea (PNG), the Bougainville struggle for autonomy from the PNG state has been marked with simultaneous intergroup struggles among the approximately 25 ethnolinguistic clusters among Bougainvilleans (Hammond, 2011). Interestingly, Bougainville has attended to its internal ethnic contours by implementing a peace process that recognises its ethnic variations and by developing a system of representation that includes clan, village, and area council chiefs (Reagan, 1999).

Practical applications of our findings may likewise be extended to regions beyond the Pacific Rim where there are latent yet fractured ethnic narratives embedded in a larger war storyline. This may be the case in the future of countries that are tribally configured, such as Afghanistan, Iraq, Libya, and Yemen. After a foreign enemy departs or an authoritarian leader falls, tribes that do not share the same ancestry, language, and territorial domains would need to strike a final peaceful arrangement among themselves, as the war-and-peace conversation veers away from a defensive armed struggle against an external enemy, to sharing dominion over ethnically contoured territory. For example, even as we write this article, there is news coming out of Libya claiming that rival tribes are violently feuding over the coming polls, in a new democracy won by a painful people's struggle against the Gaddafi dictatorship 8 months ago (Davies, 2012). Indeed, the next-level peace narratives in both territorial conflicts and democratic movements may need to be about tribal power sharing.

\section{Acknowledgments}

We gratefully acknowledge the support provided to Cristina J. Montiel from an Ateneo de Manila Loyola Schools Scholarly Work Grant and an AusAID-ALA visiting fellowship grant to the Centre for Dialogue at La Trobe University.

\section{References}

Abric, J. (1996). Specific processes of social representations. $\mathrm{Pa}$ pers on Social Representations, 5(1), 77-80.

Abric, J. (2001). A structural approach to social representations. In K. Deaux \& G. Philogene (Eds.), Representations of the social: Bridging theoretical traditions (pp. 42-47). Oxford: Blackwell. 
Abric, J. (2008, June-July). A structural approach of the social representations: The theory of the central core (Abric, 1976). Paper presented at the Ninth International Conference on Social Representations, Bali, Indonesia.

Bertrand, J. (2000). Peace and conflict in the southern Philippines: Why the 1996 peace agreement is fragile. Pacific Affairs, 73(1), 37-54.

Braun, V., \& Clarke, V. (2006). Using thematic analysis in psychology. Qualitative Research in Psychology, 3, 77101.

Buendia, R. (2005). The State-Moro armed conflict in the Philippines: Unresolved national question or question of governance? Asian Journal of Political Science, 13(1), 109 138.

Chandra, K. (2006). What is ethnic identity and does it matter? Annual Review of Political Science, 9, 397-424.

Davies, W. (2012). Rival Libyan tribes feud ahead of 'crucial' polls. BBC New Africa 2 July 2012. Retrieved from http://www.bbc.co.uk/news/world-africa-18624461

Frake, C. (1998). Abu Sayyaf: Displays of violence and the proliferation of contested identities among Philippine Muslims. American Anthropologist, 100(1), 41-54.

Gurr, T., \& Moore, W. (1997). Ethnopolitical rebellion: A crosssectional analysis of the 1980s with risk assessments for the 1990s. American Journal of Political Science 41, 10791103.

Hammond, T. (2011). Conflict resolution in a hybrid state: The Bougainville story. Retrieved from http://www. foreignpolicyjournal.com/2011/04/22/conflict-resolu

Harnischfeger, J. (2004). Sharia and control over territory: conflicts between 'settlers' and 'indigenes' in Nigeria. African Affairs, 103(412), 431-452.

Kreuzer, P. (2005). Political clans and violence in the southern Philippines. Peace Research Institute Report, 71. Retrieved from http://hsfk.de/downloads/PRIF-71.pdf

Majul, C.A. (1973). Muslims in the Philippines. Quezon City, Philippines: University of the Philippines.

McCulloch, L. (2005). Aceh: Then and Now (Minority Rights Group International Report). London: Minority Rights Group.

Milligan, J. (2001). Religious identity, political autonomy and national integrity: Implications for educational policy from Muslim-Christian conflict in the Southern Philippines. Islam and Christian-Muslim Relations, 12(4), 435448.

Montiel, C.J., \& de Guzman, J. (2011). Social representations of a controversial peace agreement: Subjective meanings of the GRP-MILF MOA. Philippine Political Science Journal, 32(55), $37-72$.
Montiel, C.J. (2010). Social representations of democratic transition: Was the Philippine People Power a non-violent power shift or a military coup? Asian Journal of Social Psychology, 13, 173-184.

Montiel, C.J., de Guzman, J., Inzon, C., \& Batistiana, B. (2010). Political positioning in asymmetric intergroup conflicts: Three cases from war-torn Mindanao. In F. Moghaddam \& R. Harre (Eds.), Words of conflict, words of war: How the language we use in political processes sparks fighting (pp. 173-187). Westport, CT: Praeger.

Moscovici, S. (1988). Notes towards a description of social representations. Journal of European Social Psychology, 18(3), 211-250.

National Statistics Office. (2002). Population growth rate at 3.56 percent in Zamboanga City: Result from the 2000 Census of Population and Housing. Retrieved from http://www.census. gov.ph/data/pressrelease/2002/pr02134tx.html

Philogene, G., \& Deaux, K. (2001). Introduction. In K. Deaux \& G. Philogene (Eds.), Representations of the social: Bridging theoretical traditions (pp. 3-7). Oxford: Blackwell.

Regan, A. (1999). Bouganville: The peace process and beyond (Submission to the Foreign Affairs Sub-committee of the Joint Standing Committee on Foreign Affairs, Defence and Trade Inquiry). Retrieved from http://ips.cap.anu.edu.au/ ssgm/resource_documents/bougainville/PDF/ajregan2.pdf

Roland-Lévy, C., \& Berjot, S. (2009). Social representations of retirement in France: A descriptive study. Applied Psychology: An International Review, 58(3), 418-434.

Sarrica, M., \& Contarello, A. (2004). Peace, war and conflict: Social representations shared by peace activists and nonactivists. Journal of Peace Research, 41, 549-568.

Sarrica, M., \& Wachelke, J. (2009). Peace and war as social representation: A structural exploration with Italian adolescents. Universitas Psychologica, 9(2), 315-330.

Schulze, K.E. (2003). The other side to Aceh's rebels. Retrieved from http://www.atimes.com/atimes/Southeast_ Asia/EG22Ae05.html

Tan, A. (2000). Armed Muslim separatist rebellion in Southeast Asia: Persistence, prospects, and implications. Studies in Conflict \& Terrorism, 23, 267-288.

Wachelke, J.F.R. (2008). Brazilian fans' social representations on soccer. International Journal of Sport Science, 4(13), 1-19.

Wagner, W., Duveen, G., Farr, G., Jovchelovitch, S., LorenziCioldi, F., Markova, I., \& Rose, D. (1999). Theory and method of social representations. Asian Journal of Social Psychology, 2(1), 95-125.

Wolter, R.P., Gurrieri, C., \& Sorribas, E. (2009). Empirical illustration of the hierarchical organization of social thought: A domino effect? Interamerican Journal of Psychology, 43(1), $1-11$. 